\title{
Analysis of surface and root-zone soil moisture dynamics with ERS scatterometer and the hydrometeorological model SAFRAN-ISBA-MODCOU at Grand Morin watershed (France)
}

\author{
T. Paris Anguela ${ }^{1}$, M. Zribi ${ }^{1,2}$, S. Hasenauer ${ }^{3}$, F. Habets ${ }^{4}$, and C. Loumagne ${ }^{5}$ \\ ${ }^{1}$ CETP/CNRS, Vélizy, France \\ ${ }^{2}$ CESBIO, Toulouse, France \\ ${ }^{3}$ Vienna University of Technology, Institute of Photogrammetry and Remote Sensing, Vienna, Austria \\ ${ }^{4}$ UMR-Sisyphe, Université Paris VI, CNRS, Paris, France \\ ${ }^{5}$ UR Hydrosystèmes et Bio-Procédés, Antony, France
}

Received: 25 June 2008 - Published in Hydrol. Earth Syst. Sci. Discuss.: 17 July 2008

Revised: 2 December 2008 - Accepted: 9 December 2008 - Published: 18 December 2008

\begin{abstract}
Spatial and temporal variations of soil moisture strongly affect flooding, erosion, solute transport and vegetation productivity. Its characterization, offers an avenue to improve our understanding of complex land surfaceatmosphere interactions. In this paper, soil moisture dynamics at soil surface (first centimeters) and root-zone (up to $1.5 \mathrm{~m}$ depth) are investigated at three spatial scales: local scale (field measurements), $8 \times 8 \mathrm{~km}^{2}$ (hydrological model) and $25 \times 25 \mathrm{~km}^{2}$ scale (ERS scatterometer) in a French watershed. This study points out the quality of surface and rootzone soil moisture data for SIM model and ERS scatterometer for a three year period. Surface soil moisture is highly variable because is more influenced by atmospheric conditions (rain, wind and solar radiation), and presents RMSE up to $0.08 \mathrm{~m}^{3} \mathrm{~m}^{-3}$. On the other hand, root-zone moisture presents lower variability with small RMSE (between 0.02 and $0.06 \mathrm{~m}^{3} \mathrm{~m}^{-3}$ ). These results will contribute to satellite and model verification of moisture, but also to better application of radar data for data assimilation in future.
\end{abstract}

\section{Introduction}

Soil moisture is the water held in the pores of the unsaturated zone. It is one of the most important soil variables, relative to climatology, hydrology and ecology (Beven and

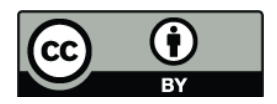

Correspondence to: T. Paris Anguela (Thais.Paris@cetp.ipsl.fr)
Fisher, 1996; Houser et al., 1998). Surface and root-zone soil moisture regulate the water and energy budgets at the soil-vegetation-atmosphere interface. Moisture content is an important parameter in watershed modeling as well, since it partially controls the partitioning of rainfall, infiltration and surface runoff and thus the hydrodynamic of the riverflow at the outlet (Koster et al., 2003).

Despite the importance of soil moisture, its accurate assessment is difficult due to strong spatial and temporal variability, due primarily to the topography, variation of the soil type and land use (Cosh et al., 2004; Famiglietti et al., 2008). Teuling and Troch (2005) reviewed several studies dealing with soil moisture variability. They found that a simple physically-based model can capture the relationship between mean soil moisture and variability. Vachaud et al. (1985) postulated that fields maintain spatial patterns of soil moisture through time. If patterns are maintained, then it is possible to minimize the number of observations without significant loss of information. Grayson and Western (1998), Mohanty and Skaggs (2001), Jacobs et al. (2004), and Cosh et al. (2004) demonstrated that a few time stable sites well represent the mean soil moisture within small watersheds. However, these studies only examined time stability for near surface soil moisture.

There are three alternative sources to estimate soil moisture dynamics over large areas: the first method is based on hydrological modeling, the second on satellite observations and the third on representative Catchments Average Soil Moisture Monitoring sites (Grayson and Western 1998).

Land surface models, can synthesize spatially distributed

Published by Copernicus Publications on behalf of the European Geosciences Union. 
Table 1. Overview of ERS scatterometer root-zone soil moisture $(0$ to $100 \mathrm{~cm}$ ) retrievals compared with observations.

\begin{tabular}{|c|c|c|c|c|}
\hline Sensor & & Data type and values & Application & Reference \\
\hline \multirow{5}{*}{ 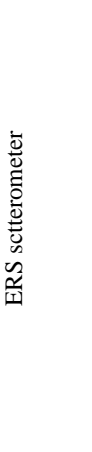 } & \multirow{5}{*}{ 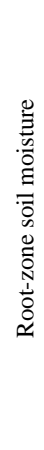 } & $\begin{array}{l}\text { RMSE: } 0.05 \mathrm{~m}^{3} \mathrm{~m}^{-3} \\
R^{2}: 0.25\end{array}$ & Ukraine & $\begin{array}{l}\text { Wagner } \\
\text { et al. }(1999 \mathrm{c})\end{array}$ \\
\hline & & $\begin{array}{l}\text { RMSE: } 0.03 \text { to } 0.07 \mathrm{~m}^{3} \mathrm{~m}^{-3} \\
R^{2}: 0.25\end{array}$ & Global & $\begin{array}{l}\text { Wagner } \\
\text { et al. (2003) }\end{array}$ \\
\hline & & $\begin{array}{l}\text { RMSE: } 0.02 \mathrm{~m}^{3} \mathrm{~m}^{-3} \\
R^{2}: 0.75\end{array}$ & NW Spain & $\begin{array}{l}\text { Ceballos } \\
\text { et al. }(2005)\end{array}$ \\
\hline & & $\begin{array}{l}\text { RMSE: } 0.05 \mathrm{~m}^{3} \mathrm{~m}^{-3} \\
R^{2}: 0.80\end{array}$ & $\begin{array}{l}\text { Russia, Ukraine, } \\
\text { Mongolia, US }\end{array}$ & $\begin{array}{l}\text { Scipal } \\
\text { et al. (2005) }\end{array}$ \\
\hline & & $\begin{array}{l}\text { RMSE: } 0.38 \mathrm{~m}^{3} \mathrm{~m}^{-3} \\
R^{2}: 0.44\end{array}$ & European forests & $\begin{array}{l}\text { Verstraeten } \\
\text { et al. (2005) }\end{array}$ \\
\hline
\end{tabular}

rainfall, land use, soil, and topographic maps to produce surface soil moisture predictions over large-spatial areas. However, the use of models is not free from errors, e.g. rainfall, soil texture, model calibration and parameter identification (Beven, 1993; Gupta et al., 1999). The SIM (SAFRANISBA-MODCOU) model is used at METEO-FRANCE in an operational mode over the entire France since 2003 (Habets et al., 2008). The SIM model is a semi-distributed model that uses a grid cell of $8 \times 8 \mathrm{~km}^{2}$ to simulate the water and energy budget at the surface, the soil moisture and the discharge of the main French rivers.

Considerable efforts have been made, over the past 3 decades, to develop remote sensing techniques for the characterization of the spatial and temporal variability of soil moisture over large regions. In particular, active and passive microwave techniques as well as interpretation tools have been developed (Jackson et al., 1996). The effectiveness of low-resolution space-borne scatterometers (active microwave) for land surface characterization has been demonstrated by a large number of studies related to moisture estimation (e.g., Frison and Mougin, 1996; Wagner et al., 1999c; Zribi et al., 2003).

Different studies (Quesney et al., 2001; Le HegaratMascle et al., 2002; Weisse et al., 2002; Oudin et al., 2003) have been performed in Grand Morin watershed with the aim to monitor soil moisture form space in an operational way, in order to improve hydrological model simulations, using soil moisture data form European Remote Sensing / Synthetic Aperture Radar (ERS/SAR). One of the conclusions of these studies is that soil moisture data assimilation showed little improvements because of the scarcity of ERS/SAR data (temporal resolution of 35 days).

In order to overcome the temporal resolution problem, we decided to work with ERS (European Remote Sensing Satellite) scatterometer soil moisture product from the Vienna University of Technology (Wagner et al., 1999c). ERS scatterometer data has the advantage to provide soil moisture data two times per week, to be freely available (http: //www.ipf.tuwien.ac.at/radar) and to provide global spatial coverage since 1991. Moreover, ERS scatterometer data has already been successfully used in other studies (e.g. Table 1).

Remote-sensing data, when combined with numerical simulation and other data, should provide estimates of soil moisture with higher spatial and temporal resolution and less error than either remotely sensed data or model simulations separately (Houser et al., 1998). In essence, the data assimilation system attempts in improving the land model performance using satellite retrievals in space and time. Via the land model, the system also propagates the surface information from the satellite into the deeper soil and thereby provides improved estimates of root-zone soil moisture (Reichle et al., 2007). A number of prior works deal with data assimilation procedures (e.g., Francois et al., 2003; Houser et al., 1998; Reichle et al., 2007; Sabater et al., 2007; Walker and Houser, 2001).

The aim of this paper is to investigate the quality of different soil moisture products in order to be used for data assimilation. The soil moisture products compared are: TDR (Time Domain Reflectometry) which is a local scale product; SIM model at $8 \times 8 \mathrm{~km}^{2}$ scale; and ERS scatterometer at a $25 \times 25 \mathrm{~km}^{2}$ scale. For each product, we will compare the data at two soil depths:

1. the soil surface (up to $5 \mathrm{~cm}$ ) which is more variable and

2. the root-zone (up to $1.5 \mathrm{~m}$ depth).

This investigation applies ERS and SIM products like they are delivered by Vienna University of Technology and Météo-France, respectively, for the purpose to see if they are able to represent the soil moisture in our particular watershed. We do not have the aim or possibility to modify these products.

The paper is set out as follows:

1. presentation of the study area and soil moisture data products;

2. examination and discussion of the results and their implications over 3 years study;

3. concluding remarks.

\section{Study area and data validation}

\subsection{Grand Morin}

The Grand Morin (France) is a tributary of the Marne river, $35 \mathrm{~km}$ east of Paris (Fig. 1). The total length of the stream is about $120 \mathrm{~km}$, for a catchment area of $1070 \mathrm{~km}^{2}$ (around $1 / 10$ of the Marne catchment area, which is a main tributary 


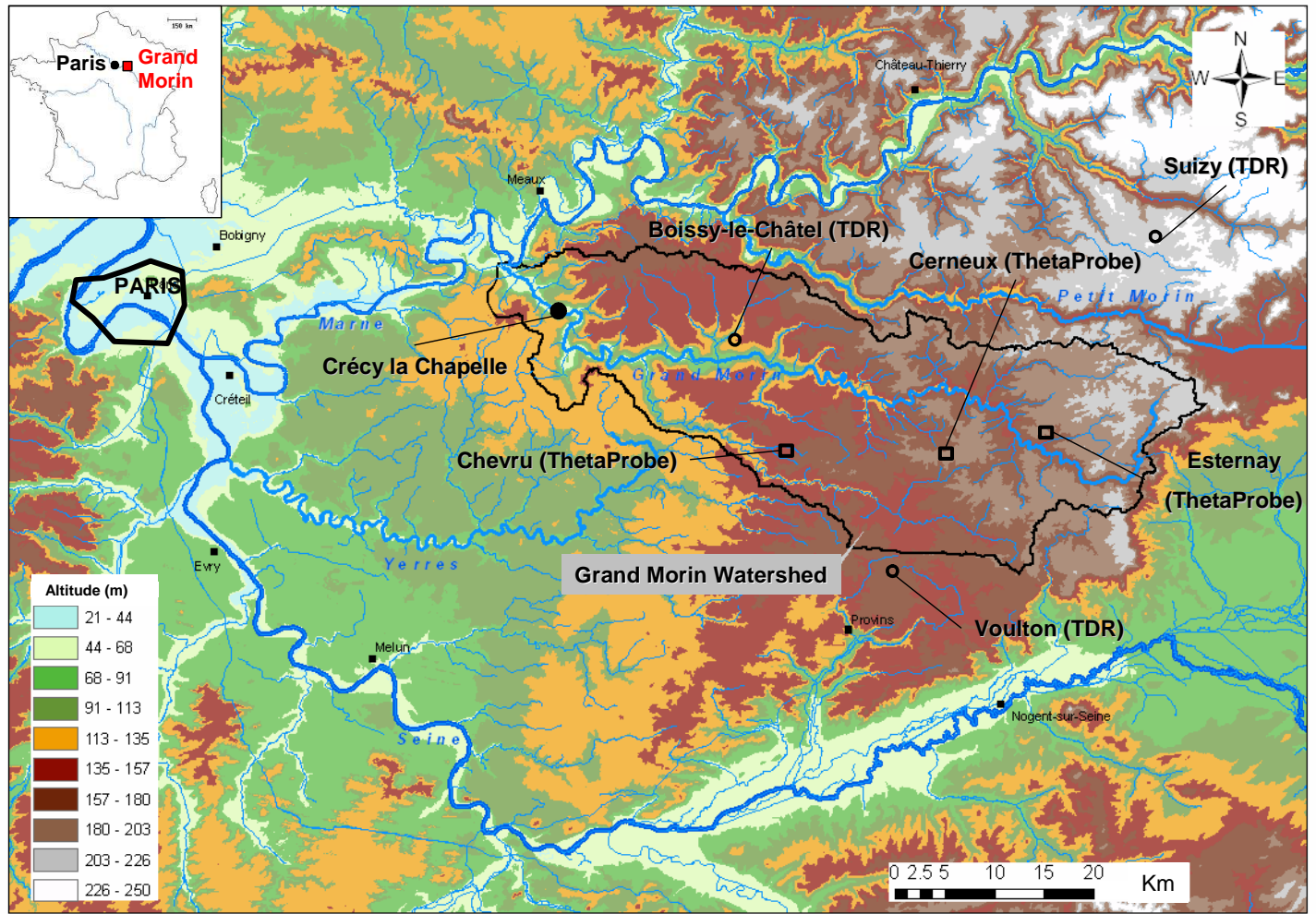

Fig. 1. Location of Grand Morin watershed, TDR and ThetaProbe.

of the Seine river). At Crécy la Chapelle the mean annual discharge is $7 \mathrm{~m}^{3} \mathrm{~s}^{-1}$. The Grand Morin basin is affected by a degraded oceanic climate, being subject to the semicontinental influence of the East of France. The temperatures are rather soft (average $11^{\circ} \mathrm{C}, 4^{\circ} \mathrm{C}$ minimum, $19^{\circ} \mathrm{C}$ maximum). The average pluviometry calculated over the period $1997-2001$ is $900 \mathrm{~mm}$. The network drains two main geological formations: the Oligocene (Rupelian limestone) and the Eocene (from Priabonian to Ypresian claystones). These two aquifer units are separated by a clayey aquitard. Soil surface elevation ranges from $40 \mathrm{~m}$ to $240 \mathrm{~m}$. The slopes of the river network range from $0.1 \%$ to $5.2 \%$. The lower stream orders mainly drain the Oligocene formation and are located on the plateaux. The agriculture area covers $76 \%$ of the basin, whereas forests and urban areas represent $19 \%$ and $5 \%$ of the basin, respectively. According to (Flipo, 2005), around 40\% of the cultivated surface is covered by wheat. The other crops (corn, peas, colza...) vary each year.

The hydrological observatory of Grand Morin watershed is monitored since 1963 by the Cemagref research institute. Insitu measurements of volumetric soil moisture are available: three automatic TDR (time domain reflectometry) recorders and three ThetaProbe sensors (Fig. 1, Table 2). TDR probes and ThetaProbe sensors were installed at different depths by constructing a trench (16 probes for TDR to the depth of $1 \mathrm{~m}$ and 2 probes for ThetaProbe at 5 and $20 \mathrm{~cm}$ depth). Then
Table 2. Location of TDR and Theta probe in Grand Morin watershed.

\begin{tabular}{lllll}
\hline \multirow{2}{*}{ TDR } & Location & $\begin{array}{l}\text { Date of } \\
\text { installation }\end{array}$ & $\begin{array}{l}\text { X Lambert } \\
\text { II (km) }\end{array}$ & $\begin{array}{l}\text { Y Lambert } \\
\text { II (km) }\end{array}$ \\
\hline \multirow{6}{*}{ Vouissy-le-Châtel } & $\begin{array}{l}\text { November 1996 } \\
\text { August 2006 }\end{array}$ & 659.1 & 2425.5 \\
& Suizy & July 2006 & 696.7 & 2402.1 \\
\multirow{2}{*}{$\begin{array}{l}\text { Theta } \\
\text { Probes }\end{array}$} & Chevru & February 2008 & 663.8 & 2433.6 \\
& Esternay & February 2008 & 675.3 & 2414.6 \\
\hline
\end{tabular}

the probes were horizontally inserted in the soil profile of the trench at different depths without disturbing the soil layer. The last step consists in refilling the trench with the original soil.

In our study, we only use data from the TDR at Boissy-leChâtel, which is the only in-situ data which presents temporal overlap with SIM and ERS scatterometer data. At Boissyle-Châtel, for each permanent TDR measurement, volumetric soil moisture is measured every $12 \mathrm{~h}$, from the top to $155 \mathrm{~cm}$ of depth (in total 16 probes, with 2 probes for the first five depths: 5, 15, 25, 35 and $45 \mathrm{~cm}$ ). The deeper the probes are, the smoother the response is. There is a good reaction to the rainfall from 5 to $35 \mathrm{~cm}$. For intermediary depths, the soil moisture presents small variations $(45,55,75 \mathrm{~cm})$. And 
near the water table, soil moisture is under the influence of the water table ( 95 to $155 \mathrm{~cm}$ ).

Surface soil moisture data corresponds to the moisture average of the two probes inserted at $5 \mathrm{~cm}$. Root-zone soil moisture data is obtained by averaging the values of the probes installed from 5 to $95 \mathrm{~cm}$ depth. We note that there are no differences for root-zone moisture average from 5 to $95 \mathrm{~cm}$ and from 5 to $155 \mathrm{~cm}$ due to water table influence.

\subsection{SIM hydrological model}

The SIM, SAFRAN-ISBA-MODCOU (Habets et al., 1999; Rousset et al., 2004), model is run operationally in real time by Mété-France. The SIM model is the combination of three independent parts. The first one is SAFRAN (Durand et al., 1993; Quintana Seguí et al., 2008), which provides an analysis of the atmospheric forcing. SAFRAN analyses are performed in homogeneous climatic zones and assume a vertical gradient of the variables in these zones. In each zone, the atmospheric forcing is interpolated hourly and on a regular $8 \times 8 \mathrm{~km}^{2}$ grid.

The second part is ISBA (Boone et al., 1999; Noilhan and Planton, 1989). The ISBA surface scheme is used to simulate the surface water and energy budgets on the $8 \times 8 \mathrm{~km}^{2}$ grid. Three soil layers are used: the surface layer of $1 \mathrm{~cm}$ depth, a root-zone layer (with a depth depending on the vegetation, and which is set to $1.5 \mathrm{~m}$ for most of crops types) and the hydrological layer (usually down to $2 \mathrm{~m}$ below the soil surface for most of crops types). The last component of the modeling system is the macroscale hydrological model MODCOU (Gomez, 2002; Ledoux et al., 1989), which simulates the riverflow and the evolution of the aquifers.

There is only one previous study presenting a verification of the SIM surface soil moisture product over France (Rüdiger et al., 2008). This study shows that good correlation exists between ERS and SIM, generally for low altitudes and low-to-moderate vegetation cover.

Our dataset comes from Seine basin simulation, which includes the Grand Morin watershed, where two aquifers are explicitly simulated: the Eocene and the chalk aquifer. The simulated variables include surface $(1 \mathrm{~cm})$ and root-zone soil moisture at which is associated to a depth of $1.5 \mathrm{~m}$ for the Grand Morin watershed, both in volumetric units.

\subsection{ERS scatterometer data}

The ERS scatterometer radar (active microwave) operates at C-band $(5.3 \mathrm{GHz})$ in vertical polarization. It has been flown on board of the European Remote Sensing Satellites ERS-1 (1991-1996) and ERS-2 (1995 up to present). Data sets are not available in the period 2001 to end 2003 due to satellite technical problems. Over land, the measured backscattering coefficient depends on soil moisture, surface roughness, vegetation characteristics and the incidence angle. Soil moisture data is retrieved from the radar backscattering coeffi- cient using a change detection method, developed at the Institute of Photogrammetry and Remote Sensing (IPF), Vienna University of Technology (TU-Wien) described by Wagner et al. (1999a, 1999c). This method has been applied with success over different climatic regions, the Canadian Prairies (Wagner et al., 1999a), the Iberian Peninsula (Wagner et al., 1999b), Ukraine (Wagner et al., 1999c) and Western Africa (Wagner and Scipal, 2000). However, because of the indirect nature of the measurements and the concurrent influence of vegetation and soil, remote sensing techniques must be verified with on-site measurements of good quality in different regions.

In the TU-Wien model, long-term scatterometer data are used to model the incidence angle dependency of the radar backscattering signal $\sigma^{\circ}$. Knowing the incidence angle dependency, the backscattering coefficients are normalized to a reference incidence angle $\left(40^{\circ}\right)$. Finally, the relative soil moisture data ranging between $0 \%$ and $100 \%$ are derived by scaling the normalized backscattering coefficients $\sigma^{\circ}(40)$ between the lowest/highest $\sigma^{\circ}(40)$ values corresponding to the driest / wettest soil conditions (Wagner, 1998).

The derived soil moisture product, surface soil moisture $\left(\mathrm{m}_{s}\right)$, represents the water content in the first $5 \mathrm{~cm}$ of the soil in relative units between totally dry conditions and total water capacity. The spatial resolution is about $50 \mathrm{~km}$ cells with $25 \mathrm{~km}$ grid spacing. The temporal resolution is approximately of two measurements per week.

In order to compare surface soil moisture $\left(\mathrm{m}_{s}\right)$ with surface TDR measurements and surface modeled moisture, $\mathrm{m}_{s}$ products were converted to physical units of $\mathrm{m}^{3} \mathrm{~m}^{-3}$ by using the $90 \%$ confidence interval of a Gaussian distribution (Pellarin et al., 2006) equal to $\mu \pm 1.65 \times \sigma$, where $\mu$ and $\sigma$ are respectively the mean and the standard deviation of the TDR or simulated data (depending on which soil moisture product $\mathrm{m}_{s}$ is compared to) in volumetric units:

$\theta(t)=\mathrm{m}_{s}(t) \times\left(\theta_{\max }-\theta_{\min }\right)+\theta_{\min }$

where $\theta(t)$ is the soil moisture content at a time $t\left[\mathrm{~m}^{3} \mathrm{~m}^{-3}\right]$, $\mathrm{m}_{s}(t)$ is the ERS scatterometer surface soil moisture [-] at a time $t, \theta_{\max }$ is the maximum wetness value $\left[\mathrm{m}^{3} \mathrm{~m}^{-3}\right]$ equal to $(\mu+1.65 \times \sigma)$ and $\theta_{\min }$ is the minimum wetness value $\left[\mathrm{m}^{3} \mathrm{~m}^{-3}\right]$ equal to $(\mu-1.65 \times \sigma)$.

With the aim to investigate the soil moisture content in the soil profile, a two-layer water model (Wagner et al., 1999c) was used to obtain root-zone soil moisture from surface soil moisture radar measurements, $\mathrm{m}_{s}$. The Soil Water Index data (SWI) was derived from $\mathrm{m}_{s}$ using, Eq. 2, and represents the root-zone soil moisture content in the first meter of the soil in relative units ranging between wilting point and field capacity.

$\operatorname{SWI}(t)=\frac{\sum_{i} \mathrm{~m}_{s}\left(t_{i}\right) e^{-\left(t-t_{i}\right) / T}}{\sum_{i} e^{-\left(t-t_{i}\right) / T}}$ for $t_{i} \leq t$ 

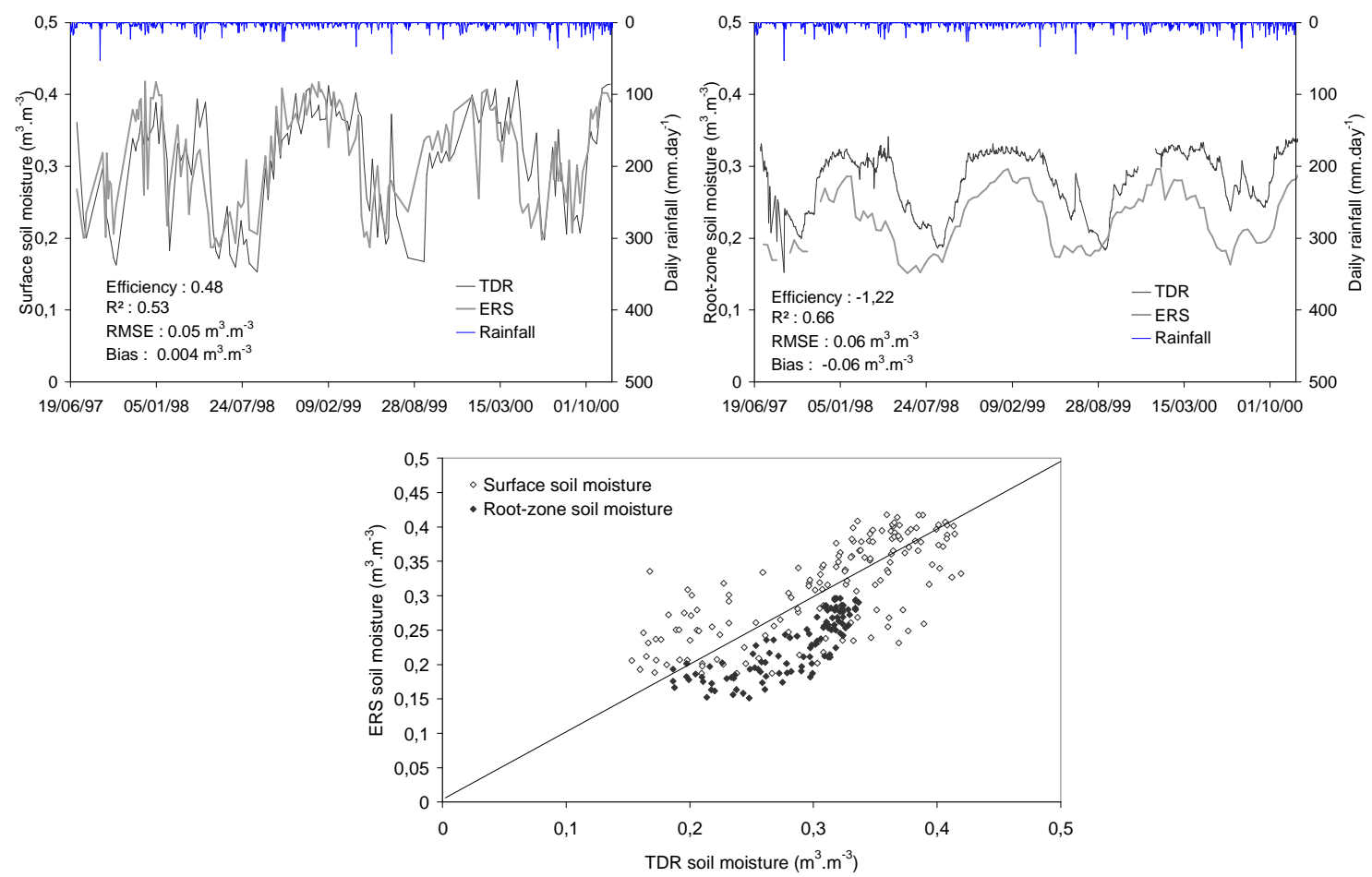

Fig. 2. Surface soil moisture (top left) and root-zone soil moisture (top right) and drawn together (bottom) measured by TDR and obtained by ERS scatterometer from June 1997 to November 2000.

where $\mathrm{m}_{s}$ is the surface soil moisture estimate from the ERS scatterometer at time $\mathrm{t}_{i}$. The parameter $T$, called the characteristic time length, represents the time scale of soil moisture variations in units of time. In our case, $T$ is set equal to 10 days.

In order to compare root-zone soil moisture from ERS scatterometer (SWI) with TDR measurements and simulated moisture, SWI products were converted to physical units $\left(\mathrm{m}^{3} \mathrm{~m}^{-3}\right)$ by using wilting point and field capacity values, Eq. 3:

$\theta(t)=\operatorname{SWI}(t) *\left(\theta_{f c}-\theta_{\text {wilt }}\right)+\theta_{\text {wilt }}$

where $\theta_{\text {wilt }}$ is the wilting point $\left(0.14 \mathrm{~m}^{3} \mathrm{~m}^{-3}\right)$ and $\theta_{f c}$ is the field capacity $\left(0.32 \mathrm{~m}^{3} \mathrm{~m}^{-3}\right)$ obtained for the Grand Morin watershed from TDR measurements.

For the comparison of all datasets, four statistical parameters were calculated: the efficiency score (Nash and Sutcliffe, 1970), the root mean square error (RMSE), the determination coefficient $\left(\mathrm{R}^{2}\right)$, and the bias between two data sets.

\section{Results}

\subsection{Comparison between TDR and ERS scatterometer soil moisture}

Surface and root-zone soil moisture at a local scale (TDR measurements) and at a coarse scale of $25 \times 25 \mathrm{~km}^{2}$ (ERS scatterometer) were compared from June 1997 to November 2000.

Surface soil moisture $(5 \mathrm{~cm}$ depth) from radar data (obtained from Eq. 1) is well correlated with in-situ measurements (Fig. 2 top left). This variation is also correlated with precipitations, which confirms that radar and TDR estimates are qualitatively coherent. The statistical results are reasonable (efficiency of 0.48 , RMSE $0.05 \mathrm{~m}^{3} \mathrm{~m}^{-3}$, low bias and $R^{2}$ of 0.53 ) due to high variability of moisture in the five first centimeters of soil (Le Morvan et al., 2008).

Root-zone soil moisture results are showed in Fig. 2 top right. ERS scatterometer data slightly underestimates in-situ measured moisture, with RMSE of $0.06 \mathrm{~m}^{3} \mathrm{~m}^{-3}$. This may be explained by two factors. The first one might be the $T$ parameter used in the semi-empirical water model (Eq. 2). Wagner et al. (1999c) showed that different $T$ values can perform better values than others. The second one, are the values of wilting point and field capacity used to convert dimensionless values of SWI to physical units (Eq. 3), which result from local scale data. However, ERS data suggests soil moisture trends in the root-zone soil profile. These results are in coherence with those obtained in previous studies (Table 1).

Fig. 2 bottom, shows that surface soil moisture is more dispersed than root-zone soil moisture. Root-zone soil moisture is an average of moisture ( 0 to $100 \mathrm{~cm}$ depth), and extreme values of moisture are smoothed. Moreover, it seems that 

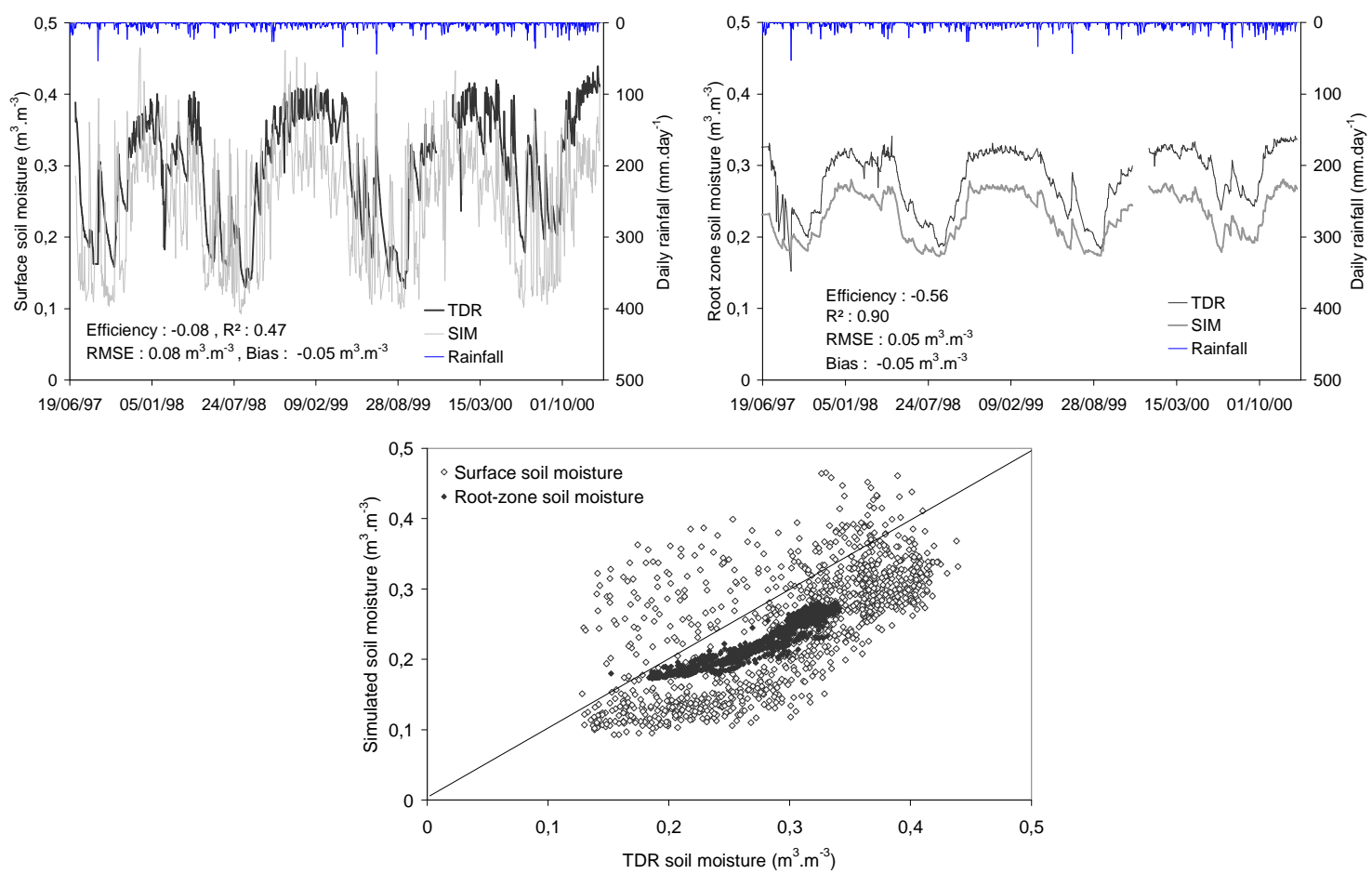

Fig. 3. Surface soil moisture (top left) and root-zone soil moisture (top right) and drawn together (bottom) measured by TDR and simulated by SIM model from June 1997 to November 2000.
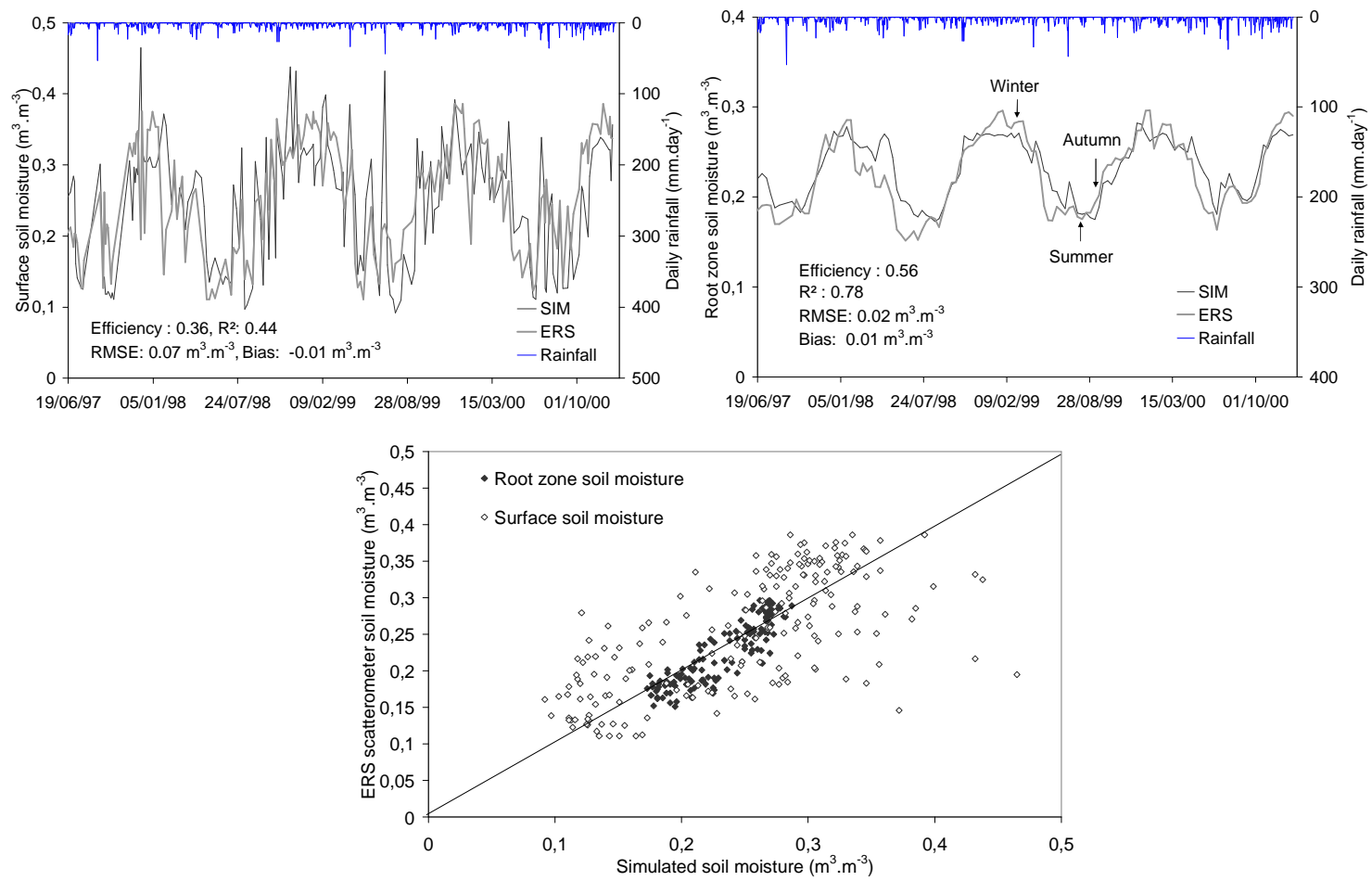

Fig. 4. Comparison of surface and root-zone soil moisture $\left(\mathrm{m}^{3} \mathrm{~m}^{-3}\right)$ for ERS scatterometer data $(5 \mathrm{~cm}$ and $1 \mathrm{~m}$ depth, respectively) and simulation ( $1 \mathrm{~cm}$ and $1.5 \mathrm{~m}$ depth, respectively), from June 1997 to November 2000. 
there is no scale effect between the two data sources and that ERS scatterometer data globally restores in-situ TDR data.

\subsection{Comparison between TDR and simulated soil moisture}

We compare soil moisture data measured (TDR) and simulated by SIM model (which corresponds to an average over $8 \times 8 \mathrm{~km}^{2}$ grid, which includes the TDR at Boissy-le-Châtel), from June 1997 to November 2000.

Surface soil moistures (Fig. 3 top left) are correlated with precipitation. The local characteristics are not well represented by the model SIM, as for instance, it represents the first centimeter of soil, which is more influenced by atmospheric conditions (rain, wind and solar radiation) than the five first centimeters of soil (TDR data). RMSE is high $\left(0.08 \mathrm{~m}^{3} \mathrm{~m}^{-3}\right)$. The comparison of surface soil moisture (Fig. 3 bottom) shows that the simulated soil moisture is highly variable and that globally underestimates in-situ data (negative bias).

Figure 3 top right, illustrates the comparison between measured and simulated root-zone soil moisture. Although soil moisture simulated takes into account for $1.5 \mathrm{~m}$, and TDR only $1 \mathrm{~m}$ (see Sect. 2.1.), the simulation is able to reproduce the main measured root-zone soil moisture. The statistical results are reasonable, with an RMSE of $0.05 \mathrm{~m}^{3} \mathrm{~m}^{-3}$, and good $R^{2}(0.90)$. These results are similar to those found by Pellarin et al. (2006), for two field sites in south-western France (RMSE equal to 0.16 and 0.12 and $R^{2}$ greater than 0.87). Bias shows that simulated data slightly underestimates TDR data (Fig. 3 bottom). However, if we compare TDR data to soil moisture simulated at the hydrological layer (from 0 to $2 \mathrm{~m}$ depth) we will observe that the hydrologic layer is more humid than the root-zone layer, because water exchanges are limited by drainage to the water table. Thus, soil moisture from the hydrological layer would lead to an estimation of soil moisture closer to soil moisture measured by TDR.

\subsection{Comparison between simulated and ERS scatterometer} soil moisture

Surface and root-zone soil moisture obtained at local scale (TDR measurements) have been successfully compared with moisture data at two different scales: ERS scatterometer and simulated moisture data, respectively. Thereafter, we compare simulated $\left(8 \times 8 \mathrm{~km}^{2}\right)$ and ERS scatterometer $\left(25 \times 25 \mathrm{~km}^{2}\right)$ moistures at a temporal and a spatial scale.

Surface soil moisture comparison between SIM and ERS (Fig. 4 top left) presents an efficiency of 0.36 and $R^{2}$ of 0.44 , which may suggest again the high variability of the first centimeter of soil. Owing to the high variability of surface soil moisture, it is not possible to observe seasonal tendencies. RMSE is acceptable and bias is low $(0.07$ and $0.01 \mathrm{~m}^{3} \mathrm{~m}^{-3}$, respectively). Root-zone soil moisture (Fig. 4 top right) presents RMSE of only $0.02 \mathrm{~m}^{3} \mathrm{~m}^{-3}$ with good $R^{2}$

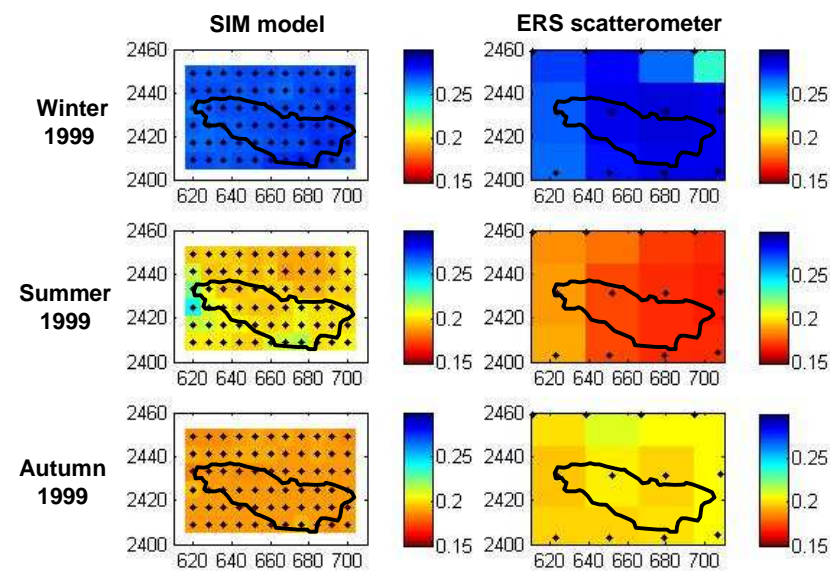

Fig. 5. Comparison of root-zone soil moisture $\left(\mathrm{m}^{3} \mathrm{~m}^{-3}\right)$ for SIM model and ERS scatterometer for the Grand Morin watershed for winter, summer and autumn period.

(0.78). There is no clear evidence of seasonal trends but often ERS root-zone soil moisture is higher than SIM moisture in winter time. In summer, ERS moisture is drier than SIM moisture. Temporal comparison of both soil moisture products is presented in Fig. 4 bottom.

For illustration purpose we have chosen to represent the spatial variation of root-zone soil moisture for model and ERS scatterometer products at the watershed scale for three particular days, which may represent the general trends for each season period in Grand Morin watershed (Fig. 4 top right):

1. a winter day which corresponds to a wet period with low vegetation,

2. a summer day which corresponds to dry period with high vegetation, and

3. an autumn day which corresponds to a dry period with low vegetation.

In winter time (Fig. 5 top), we observe similar wetness distributions for the ERS scatterometer and the SIM model in the watershed. Total moisture variation at watershed presents a maximum of $0.01 \mathrm{~m}^{3} \mathrm{~m}^{-3}$ variation at this date. One example at summer (Fig. 5 middle), shows that ERS scatterometer moisture data is drier than SIM model moisture data, with a total moisture variation in watershed of $0.03 \mathrm{~m}^{3} \mathrm{~m}^{-3}$. This can be explained by the fact that the root-zone algorithm estimates the soil moisture in the lower layer after a specific time given for percolation, and surface soil moisture events are propagated with delay resulting, in this case, lower values after a long dry phase. In autumn (Fig. 5 bottom), we have the same situation than in winter time, with low vegetation but drier conditions. The two datasets produce good spatial estimates of soil moisture also in autumn. We can conclude 
Table 3. Summary of the statistical results of the study.

\begin{tabular}{llrrr}
\hline & & TDR/ & TDR/ & SIM/ \\
& & ERS & SIM & ERS \\
\hline & Efficiency & 0.48 & -0.08 & 0.36 \\
Surface soil & $R^{2}$ & 0.53 & 0.47 & 0.44 \\
moisture & RMSE $\left(\mathrm{m}^{3} \mathrm{~m}^{-3}\right)$ & 0.05 & 0.08 & 0.07 \\
Bias $\left(\mathrm{m}^{3} \mathrm{~m}^{-3}\right)$ & 0.00 & -0.05 & 0.01 & \\
& & & & \\
& Efficiency & -1.22 & -0.56 & 0.56 \\
Root-zone soil & $R^{2}$ & 0.66 & 0.90 & 0.78 \\
moisture & RMSE $\left(\mathrm{m}^{3} \mathrm{~m}^{-3}\right.$ & 0.06 & 0.05 & 0.02 \\
& Bias $\left(\mathrm{m}^{3} \mathrm{~m}^{-3}\right)$ & -0.06 & -0.05 & -0.01 \\
\hline
\end{tabular}

that ERS scatterometer data, despite of the $25 \times 25 \mathrm{~km}^{2}$ scale, produce good quality datasets, as is the case for the modeled moisture dataset.

\section{Conclusions}

The objective of this paper was to compare three different moisture products obtained at different scales during a large period over the Grand Morin watershed. Despite the spatial and temporal variability of soil moisture (see Sect. 1), the soil moisture products compared in this paper did not seem to show variations over multiple scales. ERS scatterometer and SIM model data were able to capture the temporal and spatial variability dynamics of soil moisture in the watershed. Moreover, results are in agreement with other works (Table 1). The statistical results of the study are summarized in Table 3. The best RMSE is found by the comparison of ERS scatterometer and simulated root-zone soil moisture and is equal to $0.02 \mathrm{~m}^{3} \mathrm{~m}^{-3}$.

In general, statistical results of root-zone moisture are better than those obtained for surface soil moisture. The difference between surface and root-zone moisture can be explained by the fact that surface soil moisture is more affected by atmospheric conditions than root-zone soil moisture. The results are encouraging, and modelers may consider using these data for model validation, calibration or input (e.g. assimilation scheme) as an alternative of in-situ observations.

New sensors, like the ERS scatterometer successor Advanced Scatterometer (ASCAT) on board Metop (EUMETSAT, launched in May 2007), will provide data with higher spatial resolution $(12.5 \mathrm{~km})$ and with a higher observation frequency. Currently, EUMETSAT is implementing an operational near real-time soil moisture processing facility (Hasenauer et al., 2006).
Acknowledgements. Parts of this work have been carried out in the framework of the Satellite Application Facility on Support to Operational Hydrology and Water Management (H-SAF). The authors would like to thank Météo-France who kindly provided the soil moisture data from SIM model.

Edited by: N. Verhoest

\section{References}

Beven, K.: Prophecy, reality and uncertainty in distributed hydrological modelling, Adv. Water Resour, 16, 41-51, 1993.

Beven, K. J. and Fisher, J.: Remote sensing and scaling in hydrology, in: Scaling in Hydrology Using Remote Sensing, John Wiley \& Sons, Chichester, UK, 1-18, 1996.

Boone, A., Calvet, J.-C., and Noilhan, J.: Inclusion of a Third Soil Layer in a Land Surface Scheme Using the Force-Restore Method, J. Appl. Meteorol., 38, 1611-1630, 1999.

Ceballos, A., Scipal, K., Wagner, W., and Martínez-Fernández, J.: Validation of ERS scatterometer-derived soil moisture data in the central part of the Duero Basin, Spain, Hydrol. Process., 19, 1549-1566, 2005.

Cosh, M. H., Jackson, T. J., Bindlish, R., and Prueger, J. H.: Watershed scale temporal and spatial stability of soil moisture and its role in validating satellite estimates, Remote Sens. Environ., 92, 427-435, 2004.

Durand, Y., Brun, E., Mérindol, L., Guyomarch, G., Lesaffre, B., and Martin, E.: A meteorological estimation of relevant parameters for snow models, Ann. Glaciol., 18, 65-71, 1993.

Famiglietti, J. S., Ryu, D., Berg, A., Rodell, M., and Jackson T. J.: Field observations of soil moisture variability across scales, Water Resour. Res., 44, W01423, doi:10.1029/2006WR005804, 2008.

Flipo, N.: Modélisation intégrée des transferts d'azote dans les aquifères et les rivières : Application au bassin du Grand Morin, Ph.D. Thesis, ENSMP, Paris, 244 pp., 2005.

Francois, C., Quesney, A., Ottlé, and C.: Sequential Assimilation of ERS-1 SAR Data into a Coupled Land Surface: Hydrological Model Using an Extended Kalman Filter, J. Hydrometeorol., 4, 473-487, 2003.

Frison, P. L. and Mougin, E.: Use of ERS-1 wind scatterometer data over land surfaces, IEEE Trans. Geosci. Remote Sensing, 34, 1-11, 1996.

Gomez, E.: Modélisation intégrée du transfert de nitrate à l'échelle régionale dans un système hydrologique, Application au bassin de la Seine, Ph. D. Thesis, ENSMP, Paris, 218 pp., 2002.

Grayson, R.B., and Western, A.W.: Towards areal estimation of soil water content from point measurements: time and space stability of mean response. J. Hydrol., 207, 68-82, 1998.

Gupta, H. V., Bastidas, L. A., Sorooshian, S., Shuttleworth, W. J., and Yang, Z. L.: Parameter estimation of a land surface scheme using multicriteria methods, J. Geophys. Res., 104(D16), 19491-19503, 1999.

Habets, F., Boone, A., Champeaux, J. L., Etchevers, P., Franchistéguy, L., Leblois, E., Ledoux, E., Le Moigne, P., Martin, E., Morel, S., Noilhan, J., Quintana Seguí, P., Rousset-Regimbeau, F., and Viennot , P.: The SAFRAN-ISBA-MODCOU hydrometeorological model applied over France, J. Geophys. Res., 113, D06113, doi:10.1029/2007JD008548, 2008. 
Habets, F., Noilhan, J., Golaz, C., Goutorbe, J. P., Lacarrere, P., Leblois, E., Ledoux, E., Martin, E., Ottlé, C., and Vidal-Madjar, D.: The ISBA surface scheme in a macroscale hydrological model applied to the Hapex-Mobilhy area: Part I: Model and database, J. Hydrol., 217, 75-96, 1999.

Hasenauer, S., Wagner, W., Scipal, K., Naeimi, V., Bartalis, Z.: Implementation of near real time soil moisture products in the SAF network based on METOP ASCAT data, Proceedings of the EUMETSAT Meteorological Satellite Conference, 12-16 June 2006, Helsinki, Finland, 2006.

Houser, P. R., Shuttleworth, W. J., Famiglietti, J. S., Gupta, H. V., Syed, K. H., and Goodrich, D. C.: Integration of Soil Moisture Remote Sensing and Hydrologic Modeling Using Data Assimilation, Water Resour. Res., 34, 3405-3420, 1998.

Jacobs, J.M., Mohanty, B.P., Hsu, E.C., and Miller, D.: SMEX02: Field scale variability, time stability and similarity of soil moisture, Remote Sens. Environ., 92, 436-46, 2004.

Jackson, T. J., Schmugge, J., and Engman, E. T.: Remote sensing applications to hydrology: soil moisture, Hydrolog. Sci. J., 41(4), 517-530, 1996

Koster, R., Suarez, M., Higgins, R., and van den Dool, H.: Observational evidence that soil moisture variations affect precipitation, Geophys. Res. Lett., 30(5), 1241, doi:10.1029/2002GL016571, 2003.

Le Hegarat-Mascle, S., Zribi, M., Alem, F., Weisse, A., and Loumagne, C.: Soil moisture estimation from ERS/SAR data: toward an operational methodology, IEEE T. Geosci. Remote, 40(12), 2647-2658, 2002.

Le Morvan, A., Zribi, M., Baghdadi, N., and Chanzy, A.: Soil Moisture Profile Effect on Radar Signal Measurement, Sensors, 8, 256-270, 2008.

Ledoux, E., Girard, G., Marsilly, G., and Deschenes, J.: Spatially distributed modelling: conceptual approach, coupling surface water and groundwater, in: Unsatured Flow Hydrologic Modeling - Theory and Practice, edited by: Morel-Seytoux, H. J., Kluwer Academic Publishers, Norwell, Mass., 435-454, 1989.

Mohanty, B. P. and Skaggs, T. H.: Spatio-temporal evolution and time-stable characteristics of soil moisture within remote sensing footprints with varying soil, slope, and vegetation, Adv. Water. Resour., 24, 1051-67, 2001.

Nash, J. E. and Sutcliffe, J. V.: Riverflow forecasting through conceptual models, discussion of principles, J. Hydrol., 10(3), 282290, 1970.

Noilhan, J. and Planton, S.: A Simple Parameterization of Land Surface Processes for Meteorological Models, Mon. Weather Rev., 117, 536-549, 1989.

Oudin, L., Weisse, A., Loumagne, C., and Le Hégarat-Mascle, S.: Assimilation of soil moisture into hydrological models for flood forecasting: a variational approach, Can. J. Remote Sens., 29, 679-686, 2003.

Pellarin, T., Calvet, J.-C., and Wagner, W.: Evaluation of ERS scatterometer soil moisture products over a half-degree region in southwestern France, Geophys. Res. Lett., 33, L17401, doi:17410.11029/12006GL027231, 2006.

Quesney, A., Ottlé, C., François, C. Le Hégarat-Mascle, S., Loumagne, C., and Normand, M.: Sequential assimilation of SAR/ERS data in a lumped rainfall-runoff model with an extend Kalman filter, in: Remote Sensing and Hydrology, edited by: Owe, M., Brubaker, K., Ritchie, J., and Rango, A., IASH
Red Book Publication, 267, 495-498, 2001.

Quintana Seguí, P., Le Moigne, P., Durand, Y., Martin, E., Habets, F., Baillon, M., Canellas, C., Franchisteguy, L., and Morel, S.: Analysis of Near-Surface Atmospheric Variables: Validation of the SAFRAN Analysis over France, J. Appl. Meteorol. Clim., 47, 92-107, 2008.

Reichle, R. H., Koster, R. D., Liu, P., Mahanama, S. P. P., Njoku, E. G., and Owe, M.: Comparison and assimilation of global soil moisture retrievals from the Advanced Microwave Scanning Radiometer for the Earth Observing System (AMSR-E) and the Scanning Multichannel Microwave Radiometer (SMMR), J. Geophys. Res., 112, D09108, doi:10.1029/2006JD008033, 2007.

Rousset, F., Habets, F., Gomez, E., Le Moigne, P., Morel, S., Noilhan, J., and Ledoux, E.: Hydrometeorological modeling of the Seine basin using the SAFRANISBA-MODCOU system, J. Geophys. Res., 109, D14105, doi:14110.11029/12003JD004403, 2004.

Rüdiger, C., Calvet, J.C., Gruhier, C., Holmes, T., de Jeu, T., and Wagner, W.: An Intercomparison of ERS-Scat and AMSRE Soil Moisture Observations with Model Simulations over France, J. Hydrometeorol., in press, 2008.

Sabater, J. M., Jarlan, L., Calvet, J. C., Bouyssel, F., and De Rosnay, P.: From Near-Surface to Root-Zone Soil Moisture Using Different Assimilation Techniques, J. Hydrometeorol., 8, 194-206, 2007.

Scipal, K., Scheffler, C., and Wagner, W.: Soil moisture-runoff relation at the catchment scale as observed with coarse resolution microwave remote sensing, Hydrol. Earth Syst. Sci., 9, 173-183, 2005 , http://www.hydrol-earth-syst-sci.net/9/173/2005/.

Teuling, A. J. and Troch, P. A.: Improved understanding of soil moisture variability dynamics, Geophys. Res. Lett., 32, L05404, doi:10.1029/2004GL021935, 2005.

Vachaud, G., Passerat de Silans, A., Balabanis, P., and Vauclin, M.: Temporal stability of spatially measured soil water probability density function, Soil Sci. Soc. Am. J., 49, 822-828, 1985.

Verstraeten, W. W., Veroustraete, F., van der Sande, C. J., Grootaers, I., and Feyen, J.: Soil moisture retrieval using thermal inertia, determined with visible and thermal spaceborne data, validated for European forests, Remote Sens. Environ., 101, 299-314, 2006.

Wagner, W.: Soil Moisture Retrieval from ERS Scatterometer Data, $\mathrm{PhD}$ dissertation, Vienna University of Technology, Austria, 1998.

Wagner, W., Lemoine, G., Borgeaud, M., and Rott, H.: A study of vegetation cover effects on ERS scatterometer data, IEEE Geosci. Remote, 37b, 938-948, 1999b.

Wagner, W., Lemoine, G., and Rott, H.: A method for Estimating Soil Moisture from ERS Scatterometer and Soil Data, Remote Sens. Environ., 70, 191-207, 1999c.

Wagner, W., Noll, J., Borgeaud, M., and Rott, H.: Monitoring soil moisture over the Canadian Prairies with the ERS scatterometer, IEEE Geosci. Remote, 37a, 206-216, 1999a.

Wagner, W., and Scipal, K.: Large-scale soil moisture mapping in western Africa using the ERS scatterometer, IEEE T. Geosci. Remote, 28, 1777-1782, 2000.

Wagner, W., Scipal, K., Pathe, C., Gerten, D., Lucht, W., and Rudolf, B.: Evaluation of the agreement between the first global remotely sensed soil moisture data with model and precipitation data, J. Geophys. Res.-Atmos., 108, 4611-4626, 2003. 
Walker, J. P., and Houser, P. R.: A methodology for initializing soil moisture in a global climate model: Assimilation of near-surface soil moisture observations, J. Geophys. Res., 106(D11), 11 761$11774,2001$.

Weisse, A., Le Hegarat-Mascle, S., Aubert, D., and Loumagne, C.: The European AIMWATER project: using surface soil moisture monitoring from ERS/SAR for the rainfall-runoff modelisation, Houille Blanche, 1, 35-40, 2002.
Zribi, M., Le Hegarat-Mascle, S., Ottlé, C., Kammoun, B., and Guerin, C.: Surface soil moisture estimation from the synergistic use of the (multi-incidence and multi-resolution) active microwave ERS Wind Scatterometer and SAR data, Remote Sens. Environ., 86, 30-41, 2003. 